\title{
Platelet Cī Inhibitor
}

\section{A Secreted Alpha-Granule Protein}

Alvin H. Schmaier, Paulette M. Smith, and Robert W. Colman

Hematology/Oncology Section, Department of Medicine, Thrombosis Research Center, Temple University School of Medicine, Philadelphia, Pennsylvania 19140

\begin{abstract}
In order to characterize which proteins of the contact phase of coagulation interact with platelets, human platelets were studied immunochemically and functionally to determine if they contain $\mathbf{C} \overline{1}$ inhibitor. By means of monospecific antibody to $\mathrm{C}^{\mathbf{1}}$ inhibitor, a competitive enzyme-linked immunosorbent assay (CELISA) was developed to measure directly platelet $C \overline{\mathbf{1}}$ inhibitor. With the CELISA, from 33 to 115 ng of $C \overline{1}$ inhibitor antigen per $10^{8}$ platelets from 15 normal donors was quantified in lysates of washed human platelets solubilized in nonionic detergent. The mean concentration in $10^{8}$ platelets was $62 \pm 33 \mathrm{ng}$ (SD). Plasma $\mathbf{C} \overline{\mathbf{1}}$ inhibitor either in the platelet suspension medium or on the surface of the platelets could account for only from 6.5 to $16 \%$ of the total antigen measured in the solubilized platelets. Upon functional studies, platelets contained $84 \pm 36$ ng (SD) of $\mathrm{Ci}^{\overline{1}}$ inhibitor activity in $10^{8}$ platelets. As assessed by the CELISA, platelet $C_{\overline{1}} \bar{i}$ inhibitor antigen was immunochemically identical to plasma and purified $C_{\overline{1}} \overline{\text { inhibitor. In }}$ contrast, the mean concentration of platelet $\mathrm{C}_{\overline{1}} \mathbf{\mathrm { C }}$ inhibitor antigen in platelets from four patients with classical hereditary angioedema was $8.3 \mathrm{ng} / \mathbf{1 0}^{8}$ platelets (range, 5.3 to $11.3 \mathrm{ng} / \mathbf{1 0}^{8}$ platelets). 25 and $31 \%$ of the total platelet $C \overline{1}$ inhibitor was secreted without cell lysis from normal platelets after exposure to collagen $(20 \mu \mathrm{g} / \mathrm{ml})$ and thrombin $(1 \mathrm{U} / \mathrm{ml})$, respectively, and this secretion was blocked by metabolic inhibitors. Platelet subcellular fractionation showed that platelet $\mathrm{Ci}$ inhibitor resided mostly in alpha-granules, similar to the location of platelet fibrinogen. Thus, human platelets contained $\mathbf{C} \overline{1}$ inhibitor, which became available by platelet secretion. The identification of platelet $\mathrm{C}^{\overline{1}}$ inhibitor suggests that platelets may modulate the activation of the proteins of early blood coagulation and the classical complement pathways.
\end{abstract}

\section{Introduction}

Understanding of the role of human platelets in the activation of plasma coagulation proteolysis has been furthered by the recognition that four plasma hemostatic cofactors-fibrinogen (1-3), Factor V (4-8), Factor VIII-related antigen (9-11), and high molecular weight kininogen (12)-are contained within platelets. Similarly, the details of inhibition of coagulation and fibrinolysis reactions on or close to the platelet surface can begin to be formulated since three of the major plasma

Received for publication 20 March 1984 and in revised form 18 June 1984.

J. Clin. Invest.

(c) The American Society for Clinical Investigation, Inc.

0021-9738/85/01/0242/09 \$1.00

Volume 75, January 1985, 242-250 protease inhibitors, alpha-2-macroglobulin (13), alpha-1-antitrypsin $(13,14)$, and alpha-2-antiplasmin (15-20), are also platelet constituents. A recent preliminary report indicated that $\mathrm{C} \overline{1}$ inhibitor $\left(\mathrm{C}_{\overline{1}}^{-} \mathrm{INH}\right)^{1}$ antigen detected by immunofluorescence is present on or in platelets (21). Since $\mathrm{C}_{1} \overline{\mathrm{INH}}$ is a major plasma proteolytic inhibitor of the proteases of the initial phase of intrinsic coagulation (kallikrein, activated Factor XII, and Hageman factor fragment) (22-25) and the classical complement system (Cīr and $C \bar{r} s)(26)$, we initiated a study to determine whether $\mathrm{C}^{\overline{1}} \mathrm{INH}$ is contained with platelets. This study presents immunochemical and functional evidence for the presence of $\mathrm{C}^{\mathrm{I}} \mathrm{INH}$ in platelet granules and its secretion after platelet activation with collagen and thrombin.

\section{Methods}

Materials. Antisera to fibrinogen were purchased from Atlantic Antibodies (Scarborough, ME). Nagarse was purchased from the Enzyme Development Corp. (New York). Acid soluble collagen $(1 \mathrm{mg} / \mathrm{ml})$ was purchased from Hörmon-Chemie (Munich). Human alpha-thrombin (3125 U/mg) was a kind gift of Dr. J. Fenton, New York State Department of Health (Albany, NY). Na ${ }^{125} \mathrm{I}(50 \mathrm{mCi} / \mathrm{mmol})$ was obtained from New England Nuclear (Boston, MA). Iodogen (chloroamide, 1,3,4,6-tetrachloro-3alpha-6alpha-diphenylglycoluril) was obtained from Pierce Chemical Co. (Rockford, IL). Sodium barbital buffer, pH 8.8 was purchased from Gelman Sciences, Inc. (Ann Arbor, MI). Agarose of the highest electroendosmotic grade was obtained from FMC Corp., Marine Colloids Div. (Springfield, NJ). Firefly luciferase was purchased from Dupont, Inc. (Wilmington, DE). All other reagents were obtained from Sigma Chemical Co. (St. Louis, MO).

Plasma and platelets. Cî INH-deficient plasma from a patient with classical hereditary angioedema (Cî INH activity and antigen level, 30 $\mu \mathrm{g} / \mathrm{ml}$ [27]) and platelets from four other patients with classical hereditary angioedema with plasma $\mathrm{C}^{\overline{1}} \mathrm{INH}$ activity and antigen levels of 16 and $20 \mu \mathrm{g} / \mathrm{ml}, 52$ and $54 \mu \mathrm{g} / \mathrm{ml}, 32$ and $69 \mu \mathrm{g} / \mathrm{ml}$, and 50 and $63 \mu \mathrm{g} / \mathrm{ml}$, respectively, were directly donated to us. Pooled normal plasma (lots 120 and N10) was purchased from George King Biomedicals, Inc. (Overland Park, KS). Normal donors were males and females (aged 21-40) on no medications, including oral contraceptives, who gave their written informed consent. Fresh blood was collected, and platelet-rich plasma and platelet-poor plasma were prepared as previously described (28).

Preparation of $C \bar{I} I N H$. Cī INH was purified from plasma by polyethylene glycol precipitation, DEAE-cellulose chromatography, and Concanavalin A-Sepharose affinity chromatography according to the method of Sim and Reboul (29). Fractions containing Cí INH were detected antigenically by counterimmunoelectrophoresis (30). This preparation did not for us result in a homogenous protein upon sodium dodecyl sulfate (SDS)-polyacrylamide gel electrophoresis. Further

1. Abbreviations used in this paper: $\mathrm{C} \overline{\mathrm{I}} \mathrm{INH}, \mathrm{C} \overline{\mathrm{I}}$ inhibitor; CELISA, competitive enzyme-linked immunosorbent assay; EID, electroimmunodiffusion; RID, radial immunodiffusion. 
purification was done by performance of gel filtration over Sepharose CL-6B. Fractions containing $C \overline{1}$ INH antigen by counterimmunoelectrophoresis (30) constituted a single peak of $\sim 220,000 M_{\mathrm{r}}$ by gel filtration. By nonreduced SDS gel electrophoresis (31), purified $C \overline{1}$ INH was a single component $\left(M_{\mathrm{r}}\right.$ 107,000) (Fig. 1). Upon reduction with $2 \%$ beta-mercaptoethanol there was a slight decrease in size $\left(M_{\mathrm{r}}\right.$ $100,000)$ of the major band and the appearance of two minor components $\left(M_{\mathrm{r}} 62,000\right.$ and 46,000$)$, which constituted $<5 \%$ of the Coomassie Blue stained material by densitometer scanning. These minor components probably represented degradation products of $C \overline{1}$ INH as previously reported (29). As shown by immunodiffusion (32) the purified protein was not contaminated with human serum albumin and transferrin.

Protein determinations were performed by the methods of Bradford (33) using crystalline bovine serum albumin as the standard, and of Scopes (34).

Purified Ci INH was radiolabeled with $\mathrm{Na}{ }^{125} \mathrm{I}$ by the use of Iodogen by the method of Fraker and Speck (35). Purified Cī INH (50-200 $\mu \mathrm{g}$ in $0.02 \mathrm{M}$ Tris, $0.15 \mathrm{M} \mathrm{NaCl}, \mathrm{pH} 8.0$ ) was incubated with carrier-free $\mathrm{Na}{ }^{125} \mathrm{I}$ in a plastic vial precoated with Iodogen (1-4 $\left.\mu \mathrm{g}\right)$ for 15-35 min. The iodination reaction was stopped by the addition of sodium metabisulfite $\left(50 \mu \mathrm{g} / \mathrm{ml}\right.$ final concentration), and free ${ }^{125} \mathrm{I}$ was separated from protein-bound ${ }^{125} \mathrm{I}$ by gel filtration on a $0.8 \times 10$ $\mathrm{cm}$ column of Sephadex G-50 equilibrated in $0.02 \mathrm{M}$ Tris, $1.0 \mathrm{M}$ $\mathrm{NaCl}, \mathrm{pH} 8.0$ containing $0.25 \%$ gelatin. The specific radioactivity of the protein varied from 3 to $10 \mu \mathrm{Ci} / \mu \mathrm{g}$. The radiolabeled protein retained its full antigenic properties.

Antisera and antibodies. Antisera and antibodies to Cī INH (lots CE1-011-1 and CE1-IGG-006-3 from Atlantic Antibodies) were monospecific to purified $C_{\overline{1}} \mathrm{INH}$ and $\mathrm{C} \overline{\mathrm{l}} \mathrm{INH}$ in plasma upon double immunodiffusion (32), forming a single precipitin arc which showed complete identity. These antisera and antibodies did not cross-react upon immunodiffusion with any preparation of human and bovine serum albumin used in these studies.

Hereditary angioedema plasma was rendered totally deficient in
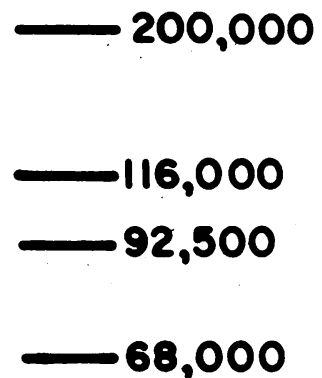

Cì INH antigen by anti-Cī INH affinity chromatography and is hereafter referred to as totally $C^{1} \bar{i}$ INH-immunodeficient plasma. Antibody to $\mathrm{C} \overline{1} \mathrm{INH}$ was covalently linked to cyanogen bromideactivated-Sepharose 4B. $7 \mathrm{ml}$ of fresh-frozen hereditary angioedema plasma were applied to a $1-\mathrm{ml}$ anti-Cî INH-Sepharose $4 \mathrm{~B}$ column and fractions, that did not adhere to the column, and were the least diluted with buffer, were collected in $0.5-\mathrm{ml}$ aliquots and rapidly refrozen at $-70^{\circ} \mathrm{C}$. This artifically produced, totally $\mathrm{Ci}$ INH-immunodeficient plasma did not form a precipitin arc with anti-Cī INH antibody upon immunodiffusion, and upon a competitive enzyme-linked immunosorbent assay (CELISA) for Cī INH antigen produced no competitive inhibition, indicating that the $\bar{C} \overline{1}$ INH concentration in the artificially depleted plasma was $<25 \mathrm{ng} / \mathrm{ml}$ (see below).

Assays. Antigenic Cī INH was quantified by radial immunodiffusion (RID) (36) and electroimmunodiffusion (EID) (37). RID was performed on $74 \times 50 \mathrm{~mm}$ glass plates covered with $7 \mathrm{ml}$ of $1 \%$ agarose in sodium barbital buffer $\mathrm{pH} 8.8, \tau / 2=0.0375$ containing $1 \%$ antiserum. Samples were placed into $2.5-\mathrm{mm}$ diam wells and allowed to diffuse for $60 \mathrm{~h}$. EID was performed as previously reported (12). In all instances where purified $\mathrm{C} \overline{1} \mathrm{INH}$ was compared with plasma $\mathrm{C} \overline{\mathrm{i}} \mathrm{INH}$, the purified $\mathrm{Ci}^{-} \mathrm{INH}$ was diluted in totally $\mathrm{Ci}_{\mathrm{I}} \mathrm{INH}$-immunodeficient plasma.

CELISA for $C \bar{I} I N H$. Plasma and platelet concentrations of $C \overline{1}$ INH were determined by a CELISA for $\mathrm{Ci}$ INH, which was performed as previously reported for high molecular weight kininogen (12). Goat anti-human Cî INH was the primary antibody and rabbit anti-goat antibody conjugated with alkaline phosphatase was used as the second antibody. The CELISA assay was usually performed with pooled normal human plasma as the standard. The concentration of Cì INH in the pooled normal plasmas was determined by standardization with purified Cī INH. Purified Cì INH was diluted in totally Cì INHimmunodeficient plasma according to its protein concentration as determined by the Scopes protein assay (34). The amounts of Cī INH antigen in two pools of normal human plasma (lots 120 and N10) were then compared with the purified $C \overline{1}$ INH diluted in totally $C \overline{1}$ INH-immunodeficient plasma by RID with anti-Cī INH antisera. All subsequent dilutions of pooled normal plasma were based on the amount of $\mathrm{C}^{\mathrm{I}} \mathrm{INH}$ antigen determined in the pools.

By the CELISA, samples for the standard curve (purified Cī INH, plasma, and unknowns [plasma, solubilized platelets]) were assayed at 10 different dilutions in triplicate. All data were analyzed on a TRS80 model III or IV computer (Tandy Corp., Radio Shack Div., Fort Worth, TX). Raw optical density readings were averaged after the blanks were subtracted. Outliers were defined as points with a $>10 \%$ SD. A best-fit standard curve was determined by an iterative computer program that uses a four-parameter logistic function for a sigmoid line fit of the standard curve (38). This program yields a semilogarithmic graph in which the ordinate is the optical absorbance calculated in relative values from 0 to 1 , and the abscissa is the absolute amount of antigen incubated with antisera. Unknown samples were determined by linear least squares regression from the standard curve of the iterative program, and the calculated slope of the regression line was an estimate of the specific activity of the sample (38). Test-sample determinations that were considered valid were computed results that fell on the linear portion of the standard curve for the individual assay and were characterized by a regression analysis with $P<0.05$ by an $F$ test on the determination of the line and by a $t$ test against the null hypothesis that the slope of the line equals zero. Immunochemical identity of the slope of the linear portions of the standard curves of purified, plasma, and platelet Cì INH was determined by two-tailed paired $t$ testing and a modified linear regression analysis of Youden (39) where the null hypothesis states that the slope of the line determined equals one.

Preparation of washed platelets. Fresh platelets were washed by a combination of albumin density gradient centrifugation and gel filtration as previously reported (12). In the determinations of all fresh platelet samples for supernatant and total $\mathrm{C}^{\overline{1}} \mathrm{INH}$ values, blood for plateletrich plasma was collected into anticoagulant that contained prostaglandin
Figure 1. Purified Cī INH $(10 \mu \mathrm{g})$ was electrophoresed on a $7.5 \%$ nonreduced SDS-polyacrylamide gel. 
$E_{1}$ (final concentration $1 \mu \mathrm{M}$ ), and these same platelets were gel filtered with buffer that also contained prostaglandin $E_{1}$ at the same concentration. Total platelet $\mathrm{C} \overline{1} \mathrm{INH}$ antigen was determined on washed platelets solubilized with $0.5 \%$ Triton $\mathrm{X}-100$ for $30 \mathrm{~min}$ at $23^{\circ} \mathrm{C}$. In independent studies, the presence of Triton did not interfere with the antigen determination of plasma $\mathrm{C} \overline{\mathrm{I}} \mathrm{INH}$.

Functional activity of platelet $C \bar{I} I N H$. Glycoprotein extracts of platelets were prepared as previously reported (40) from platelet-rich plasma. Platelets $\left(1.14 \times 10^{10}\right.$ platelets) from platelet-rich plasma were separated from plasma by centrifugation, gel-filtration over Sepharose 2B, and recentrifugation. After solubilization of the platelet pellet with $0.2 \%$ Triton X-100, the supernatant was placed on a Concanavalin ASepharose column in order to obtain a partially purified platelet extract. The eluate after introduction of $1 \mathrm{M}$ alpha-methylmannoside was collected and concentrated to $1 / 1,000$ of the starting volume of plateletrich plasma. The amount of plasma $\mathrm{C} \overline{1} \mathrm{INH}$ contaminating the platelet extract was estimated by determination of the recovery of ${ }^{125} \mathrm{I}-\mathrm{C} \overline{1}$ INH added to the starting platelet-rich plasma in the final material.

Functional Ci INH activity in the platelet glycoprotein extract was determined by the ability of the partially purified platelet material to neutralize the amidolytic activity of purified kallikrein (27). $60 \mu \mathrm{l}$ of platelet extract, pretreated for $2 \mathrm{~h}$ at $23^{\circ} \mathrm{C}$ with methylamine to inactivate alpha-2-macroglobulin (four parts platelet extract to one part $0.2 \mathrm{M}$ methylamine, $\mathrm{pH} 7.4$ [27]) was incubated with $0.3 \mu \mathrm{g}$ of purified kallikrein $\left(7.8 \times 10^{-8} \mathrm{M}\right)(27)$. At precise intervals $(5,15,25$, $35 \mathrm{~min}$ ), $10 \mu \mathrm{l}$ of the mixture was removed and the residual kallikrein amidolytic was determined as previously reported (27). The amount of $\mathrm{C}^{\mathrm{I}} \mathrm{INH}$ activity in the platelet extract was calculated by an integrated second-order reaction equation: $(1 / I N H-K) \ln [K(I N H$ $-K \cdot I N H) / I N H(K-K \cdot I N H)]=k^{\prime \prime} T(41)$, where $T$ is the time of the incubation, $k^{\prime \prime}$ is the second-order rate constant for Cī INH inhibition of kallikrein $\left(1.7 \times 10^{4} \mathrm{M}^{-1} \mathrm{~s}^{-1}\right)(42), K$ is the concentration of kallikrein, and $K \cdot I N H$ is the concentration of kallikrein lost by complexing with $\mathrm{C} \overline{\mathrm{I}} \mathrm{INH}$ at a given incubation time. The amount of Cí INH $(I N H)$ was calculated iteratively with a TRS-80 model III computer.

Indirect antibody consumption assay to determine platelet-associated Ci INH. $7.5 \mathrm{ml}$ of fresh washed platelets $\left(1.5 \times 10^{9}\right.$ platelets $\left./ \mathrm{ml}\right)$, pretreated with $1 \mu \mathrm{M}$ prostaglandin $E_{1}$ and prepared by albumin density gradient centrifugation and gel filtration, was incubated for $\mathbf{4 5}$ min at $37^{\circ} \mathrm{C}$ with an equal volume of anti-Cì INH antibody. The antibody had previously been diluted to twice its optimal titer in 0.01 $M$ sodium phosphate, $0.15 \mathrm{M} \mathrm{NaCl}, \mathrm{pH} 7.4$ containing $0.05 \%$ Tween20 and a 1:250 dilution of totally $\mathrm{C}_{1} \mathrm{INH}$-immunodeficient plasma and centrifuged at $100,000 \mathrm{~g}$ for $30 \mathrm{~min}$ in an ultracentrifuge (model L3-50; Beckman Instruments, Inc., Palo Alto, CA) to remove aggregates. A second $7.5-\mathrm{ml}$ aliquot of identically washed platelets was centrifuged at $12,000 \mathrm{~g}$ in an Eppendorf Centrifuge (Brinkmann Instruments, Inc., Westbury, NY), and the supernatant was incubated 1:1 with anti-Ci INH antibody prepared as described above. After completion of the incubations and a 4-min centrifugation at $12,000 \mathrm{~g}$ in the centrifuge, the antibody adsorbed with platelets was compared with that adsorbed with supernatant on the CELISA by use of known amounts of purified Cî INH antigen in order to determine a standard curve.

Platelet secretion studies. Fresh platelets washed by albumin density gradient centrifugation and gel filtration were divided into four aliquots of from 5 to $7 \mathrm{ml}$ each in $16 \times 95 \mathrm{~mm}$ flat-bottomed polystyrene tubes (No. 62.492; Sarstedt, Inc., Princeton, NJ) and placed into a $37^{\circ} \mathrm{C}$ water bath. The sample for total platelet $\mathrm{C}^{\overline{1}} \mathrm{INH}$ was solubilized by $0.5 \%$ Triton $\mathrm{X}-100$ for $45 \mathrm{~min}$ at $37^{\circ} \mathrm{C}$. The sample for platelet supernatant $C_{1} \overline{I N H}$ was obtained by the centrifugation at $12,000 \mathrm{~g}$ of an aliquot of platelets for $4 \mathrm{~min}$ followed by collection of the supernatant and incubation for $45 \mathrm{~min}$ at $37^{\circ} \mathrm{C}$. Washed platelets used in agonist studies were incubated for $30 \mathrm{~min}$ at $37^{\circ} \mathrm{C}$ in the absence or presence of the combined metabolic inhibitors antimycin $A(15 \mu \mathrm{g} /$ $\mathrm{ml}), 2$-deoxy-D-glucose $(30 \mathrm{mM})$, and D-gluconic acid $\delta$-lactone (10 $\mathrm{mM})(43,44)$. At the end of the incubation, the tubes were placed into a $37^{\circ} \mathrm{C}$ water bath with stirring at $1,200 \mathrm{rpm}$, and collagen (20 $\mu \mathrm{g} / \mathrm{ml})$ or thrombin $(1 \mathrm{U} / \mathrm{ml})$ was added. After $10 \mathrm{~min}$, the agonisttreated samples were centrifuged at $12,000 \mathrm{~g}$ for $4 \mathrm{~min}$ and the supernatants were collected. At the end of the secretion experiment, 0.1-ml aliquots were removed from the total, supernatant, agonisttreated, and agonist-plus-metabolic inhibitor-treated samples, and mixed with an equal volume of a mixture of one part $77 \mathrm{mM}$ EDTA, pH 7.4 and nine parts ethanol. These samples were later assayed for total adenine nucleotide (ADP and ATP) content according to the method of Holmsen et al. (45). Similarly, $0.2 \mathrm{ml}$ of each sample was obtained for the determination of platelet lactic dehydrogenase loss according to the method of Wroblewski and Ladue (46). Platelet alpha-granule secretion was assessed by measurement of low affinity platelet Factor 4 by the method of Rucinski et al. (47). The remaining material was used to assay for $\mathrm{Ci}^{-1}$ INH antigen by the CELISA. All samples were stored at $-70^{\circ} \mathrm{C}$ until assay. Each experiment used combined washed platelets from two normal donors. Percentage secretion (or loss) was determined by the ratio of the supernatant of the agonist-treated specimen to the total platelet lysate after the value of the nonactivated platelet supernatant was subtracted from both. All values represent the percentage of the total amount of each constituent found in the platelet. Washed platelets were also used to prepare Triton-insoluble cytoskeletons according to the method of Tuszynski et al. (48).

Platelet subcellular fractionation. Platelet subcellular fractionation was performed according to the technique of Fukami et al. (49). In each preparation, platelet-rich plasma from $450 \mathrm{ml}$ blood was collected, made $5 \mathrm{mM}$ with EDTA, and pelleted by centrifugation at $3,000 \mathrm{~g}$ for $10 \mathrm{~min}$ at $4^{\circ} \mathrm{C}$. The platelet pellet was suspended in $30 \mathrm{mM}$ Hepes, 5 mM EDTA, and $0.15 \mathrm{M} \mathrm{NaCl}, \mathrm{pH}$ 6.5. After it was washed by centrifugation twice more at $3,000 \mathrm{~g}$ for $10 \mathrm{~min}$ at $4^{\circ} \mathrm{C}$, the pellet was resuspended in $40 \mathrm{ml}$ of the same medium containing $20 \mu \mathrm{M}$ rotenone, $5 \mathrm{mM} 2$-deoxy-D-glucose, and $10 \mathrm{mM}$ D-gluconic acid $\delta$-lactone and incubated at $37^{\circ} \mathrm{C}$ for $20 \mathrm{~min}$. Then, $3 \mathrm{mg}$ nagarse and $20 \mathrm{mg} \mathrm{ATP}$ were mixed into the suspension at $37^{\circ} \mathrm{C}$. $5 \mathrm{~min}$ later, $20 \mathrm{mg}$ soybean trypsin inhibitor was added to neutralize the nagarse, and the platelets were centrifuged at $3,000 \mathrm{~g}$ for $10 \mathrm{~min}$ at $4^{\circ} \mathrm{C}$. The pellet was then resuspended in $25 \mathrm{ml}$ of $0.01 \mathrm{M}$ Hepes, $1 \mathrm{mM}$ EDTA, and $0.25 \mathrm{M}$ sucrose, pH 7.4 and homogenized twice in a French pressure cell (50) at 500 pounds per square inch, with one centrifugation in between the two homogenizations so that only the unbroken cells were subjected to the second homogenization. $5 \mathrm{ml}$ of the combined homogenate was set aside and $20 \mathrm{ml}$ was used for fractionation. Differential centrifugation of the homogenate resulted in the isolation of four fractions: $F_{1}, 1,000$ $g \times 22 \mathrm{~min}$ pellet; $\mathrm{F}_{2}, 12,000 \mathrm{~g} \times 20 \mathrm{~min}$ pellet; $\mathrm{F}_{3}, 100,000 \mathrm{~g} \times 60$ min pellet; and $F_{4}$, the $100,000 \mathrm{~g}$ supernate. The granule fraction, $F_{2}$, was then divided in half, and one half was applied to a 0.8 to $2.0 \mathrm{M}$ sucrose step gradient in $0.2-\mathrm{M}$ increments (51). After centrifugation at $100,000 \mathrm{~g}$ for $60 \mathrm{~min}$, five distinct areas were collected: A, 0.25-1.0 $M$ sucrose; $B, 1.0-1.3 \mathrm{M}$ sucrose; $C / D, 1.3-1.8 \mathrm{M}$ sucrose; $\mathrm{E}, 1.8-2.0$ $M$ sucrose; and $F$, a pellet. Before assay, fractions $F_{4}$ and $A-E$ of the $F_{2}$ were dialyzed against $0.01 \mathrm{M}$ Hepes, $1 \mathrm{mM}$ EDTA, pH 7.4, lyophilized, and resuspended in $5 \mathrm{ml}$ of the dialysis buffer. All fractions were treated with $0.5 \%$ Triton $\mathrm{X}-100$ before assay. $\mathrm{C} \overline{\mathrm{I}}$ INH antigen was assayed by CELISA. $\beta$ - $N$-acetyl-glycosaminidase was assayed by the technique of Day et al. (52). Fibrinogen was assayed by EID (37). Serotonin was assayed by the technique of Weissbach et al. (53). Only preparations that had a recovery $\geq 60 \%$ for total protein, $C_{\overline{1}} \mathrm{INH}$, fibrinogen, $\beta$ - $N$-acetyl-glucosaminidase, and serotonin were used in the analysis. The relative specific amounts of each marker in the preparation were calculated from the ratio of the specific amount of the marker in the fraction (amount antigen or activity per milligram total protein) to the specific amount of the marker in the total platelet lysate.

\section{Results}

CELISA for Cī INH. A CELISA was developed to quantitate and characterize directly $\mathrm{C}_{1} \overline{1}$ INH in platelets. The typical competition inhibition curves for this assay with monospecific 
antibody to $C_{1}^{-1}$ INH are given in Fig. 2. On the CELISA, the amount of measured optical density from hydrolysis of the substrate was inversely proportional to the amount of soluble antigen present in the incubation mixture. In the CELISA, Cì INH antigen in normal plasma was immunochemically identical, giving a parallel standard curve in its linear portion with purified $C \bar{l}$ INH (two-tailed $P>0.2$ by modified Youden analysis and $>0.1$ by paired $t$. test) and with purified $C \overline{1}$ INH reconstituted in total $\mathrm{C}_{\overline{1}} \mathrm{INH}$-immunodeficient plasma (twotailed $P>0.3$ by modified Youden analysis and $>0.1$ by paired $t$ test) (Fig. 2). Two batches of pooled normal plasma were determined to contain 230 and $236 \mu \mathrm{g} / \mathrm{ml} \mathrm{Cī} \mathrm{INH} \mathrm{antigen,}$ respectively, by RID comparison with purified $\mathrm{C}^{-1}$ INH reconstituted into total $\mathrm{C} \overline{1}$ INH-immunodeficient plasma. When pooled normal plasma was used for the standard curve, the CELISA assay typically gave a linear curve from 10 to $150 \mathrm{ng}$. In a comparison of the CELISA with EID, 10 individual normal plasmas on the CELISA had a mean \pm SD $C^{-1}$ INH antigen concentration of $233 \pm 27 \mu \mathrm{g} / \mathrm{ml}$ (range, 202-264 $\mu \mathrm{g}$ / $\mathrm{ml}$ ), which was not significantly different (two-tailed $P>0.1$ by paired $t$ test) from the mean value of $256 \pm 42 \mu \mathrm{g} / \mathrm{ml}$ (range, 196-318 $\mu \mathrm{g} / \mathrm{ml}$ ) of the same plasmas determined by EID. The interassay coefficient of variation of a single plasma sample assayed four times over a 1-mo period was $3.3 \%$. Moreover, the presence of complex formation of $\mathrm{C}^{-1}$ INH with its proteases after plasma activation did not influence the absolute amount of $C \overline{1}$ INH antigen measured in the plasma by CELISA. When the plasma concentration of $C \overline{1}$ INH in a fresh sample was compared with that of the same sample that had been activated by freezing and thawing four times, the $C \overline{1}$ INH antigen concentration was the same in both plasmas.

Characteristics of washed platelets. To estimate the amount of plasma $C \overline{1}$ INH that might be contaminating the final washed platelets to be used in these studies, tracer studies were performed with ${ }^{125} \mathrm{I}-\mathrm{C} \overline{1}$ INH added to the starting platelet-rich plasma. (Table I shows one representative experiment of three.) ${ }^{125} \mathrm{I}-\mathrm{C} \overline{\mathrm{I}} \mathrm{INH}(1.35 \mu \mathrm{g}$ with a specific radioactivity of $2 \mu \mathrm{Ci} / \mu \mathrm{g})$ was introduced into the platelet-rich plasma, incubated for 5 min at $37^{\circ} \mathrm{C}$, and traced through the washing procedure. The final amount of the total ${ }^{125} \mathrm{I}-\mathrm{C} \overline{1}$ INH tracer associated with

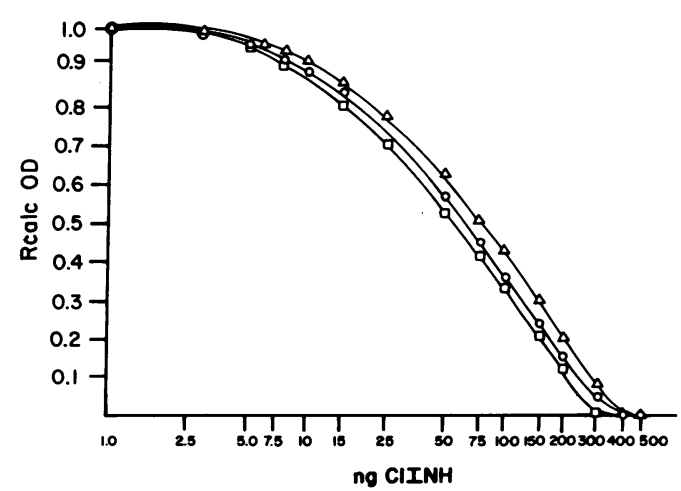

Figure 2. Standard competitive inhibition curve obtained with $C \overline{1}$ INH antibody on the CELISA. Along the ordinate is the relative absorbance (Rcalc OD), and along the abscissa is the absolute amount of antigen incubated with the antibody. Inhibition curves produced by: $\Delta$, purified $C \overline{1} \mathrm{INH}$; $\square$, pooled normal plasma; or $O$, total Cì INH-immunodeficient plasma reconstituted with purified Cī INH.
Table I. ${ }^{125}$ I-CĪ INH Tracer Studies with Washed Platelets*

\begin{tabular}{llc}
\hline Platelet preparation & $\begin{array}{l}\text { Total } \\
\text { radioactivity }\end{array}$ & Recovery§ \\
\hline & $n C i$ & $\%$ \\
Platelet-rich plasma & 1923 & 100 \\
Washed platelets & 0.333 & 0.017 \\
Supernatant washed platelets & 0.196 & 0.01 \\
\hline
\end{tabular}

* $1.35 \mu \mathrm{g}$ of ${ }^{125} \mathrm{I}-\mathrm{C} 1 \overline{1} \mathrm{INH}$ (specific radioactivity $2 \mu \mathrm{Ci} / \mu \mathrm{g}$ ) was added to platelet-rich plasma, and the platelets were washed by albumin density gradient centrifugation and gel filtration. The final washed platelets had a concentration of 370,000 platelets/ $\mu$ l. The data presented are from one representative experiment of three.

f Amount given represents the total radioactivity present in the material.

$\S$ Determined from the ratio of the total radioactivity in each material to the total radioactivity of the platelet-rich plasma $\times 100$.

the washed platelets $\left(3.70 \times 10^{8}\right.$ platelets $\left./ \mathrm{ml}\right)$ was equal to 0.229 of the $1,350 \mathrm{ng}$ of the ${ }^{125} \mathrm{I}-\mathrm{C} \overline{1} \mathrm{INH}$ added to the plateletrich plasma, or $0.017 \%$ of the original amount of the radiolabel. This finding indicated that for every milliliter of washed platelets, $39 \mathrm{ng}$ of plasma $\mathrm{C} \overline{1} \mathrm{INH}$ or, if the ${ }^{125} \mathrm{I}-\mathrm{C} \overline{1} \mathrm{INH}$ tracer was in equilibrium with the platelet and other $\mathrm{C}_{1}^{-} \mathrm{INH}, 10.5$ ng $\mathrm{C}^{\overline{1}} \mathrm{INH} / 10^{8}$ platelets, would be present in the suspending medium if $1 \mathrm{ml}$ plasma contained $230 \mu \mathrm{g} C \overline{1}$ INH antigen. The equilibrium of the ${ }^{125} \mathrm{I}-\mathrm{C} \overline{1}$ INH tracer with platelet-rich plasma was assessed in additional experiments in which the ${ }^{125} \mathrm{I}-\mathrm{C} \overline{1}$ INH tracer was incubated with the platelets in plasma for $3 \mathrm{~h}$. In those experiments there was only a $2 \%$ increase in the amount of the radiolabel associated with platelets at the longer incubation. In the CELISA, the amount of antigen directly measured was that present in $0.1 \mathrm{ml}$ of washed platelets. Thus, only 3.9 or $10.5 \mathrm{ng} / 10^{8}$ platelets of the $\mathrm{C} \overline{1}$ INH antigen present in each assay of solubilized platelets could be estimated to be from plasma $\mathrm{C}^{-1}$ INH contamination.

Determination of platelet-associated plasma $C \bar{I} I N H$. The amount of plasma $C \overline{1}$ INH estimated by the ${ }^{125}$ I-tracer experiment that could contaminate the washed platelets can describe only a lower limit of possible plasma contamination. The presence of soluble, tightly bound, and nonexchangeable plasma Cí INH on the platelet surface could possibly account for additional plasma contamination of the washed platelets. To evaluate this possibility an indirect antibody consumption assay was designed to compare antibody adsorbed with platelets with antibody diluted with platelet supernatant on the CELISA. The antibody was diluted in totally $\mathrm{C}^{\overline{1}} \mathrm{INH}$-immunodeficient plasma to provide excess normal immunoglobulin, which prevents nonspecific antibody association with platelets via platelet Fc receptors. Cì INH antibody was incubated with whole platelets to determine whether plasma $\mathrm{C} \overline{1}$ INH tightly bound to platelets would adsorb the anti-Cī INH antibody, as determined by its ability to detect fixed amounts of purified Cì INH. Incubation of platelets under these conditions and centrifugation was associated with $<1 \%$ lysis as determined by lactic dehydrogenase loss. As shown in Fig. 3, when antibody adsorbed with platelets $\left(1.5 \times 10^{9}\right.$ platelets $\left./ \mathrm{ml}\right)$ was incubated with purified $\mathrm{C} \overline{1} \mathrm{INH}$, a superimposable, parallel standard curve (two-tailed $P>0.1$ by modified Youden analysis and $P$ $>0.2$ by paired $t$ test) was produced when compared with 


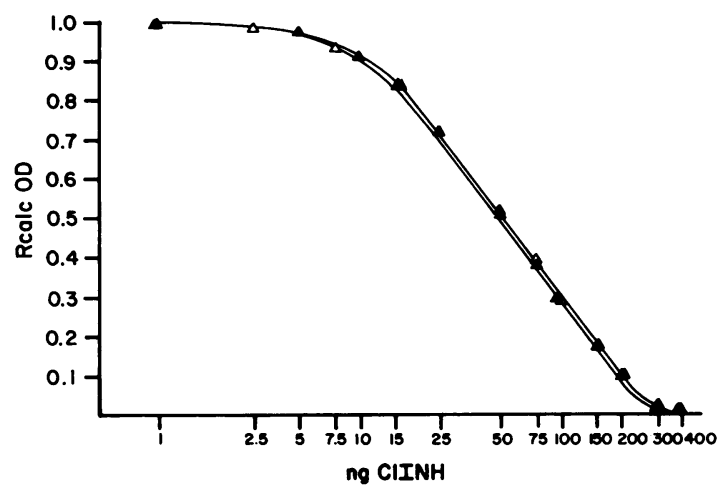

Figure 3. Competitive inhibition standard curve produced by purified Cî INH with antibody adsorbed with platelets and unadsorbed antiCì INH antibody. Anti-Cî INH antibody was incubated with equal volumes of whole washed platelets or the supernatant of the platelet suspension. The platelet-adsorbed antibody and unadsorbed antibody were then incubated with equal amounts of purified Cí INH to produce a standard curve by use of the CELISA (Methods). The standard curve produced by platelet-adsorbed antibody ( $\Delta$ ) is plotted along with the standard curve produced by unadsorbed antibody $(\Delta)$. In this assay the ordinate expresses relative absorbance (Rcalc OD), and the abscissa shows the absolute amount of antigen incubated with antibody.

purified $\mathrm{C} \overline{\mathrm{I}}$ INH incubated with unadsorbed antibody. This result showed that incubation of whole platelets with anti-Cí INH antibody did not lead to a decrease in the titer of the antibody that could interact with purified $\mathrm{C}^{-} \mathrm{INH}$. This finding indicated that no detectable plasma $\mathrm{C} \overline{1}$ INH $\left(<6.6 \mathrm{ng} / 10^{8}\right.$ platelets) was tightly bound to the platelet surface since the standard curve would have been flattened and shifted to the left if the titer of the platelet-adsorbed antibody had been decreased.

Ci INH in washed platelets. Since the ${ }^{125} \mathrm{I}-\mathrm{C} \overline{\mathrm{I}}$ INH tracer studies suggest that 3.9 or $10.5 \mathrm{ng} \mathrm{C}^{\overline{1}} \mathrm{INH}$ antigen $/ 10^{8}$ platelets measured in each aliquot of washed platelets could arise from plasma contamination, the supernatant suspensions of each of the washed platelets from eight donors used in the determination of total platelet $C \overline{1}$ INH were directly measured for $C^{-1}$ INH antigen by CELISA. In the eight individual donors, the mean amount of $\mathrm{C} \overline{1}$ INH antigen directly measured in the platelet supernatants was $7.9 \pm 3.2 \mathrm{ng} / 10^{8}$ platelets (range, $3.7-13 \mathrm{ng}$ ) $10^{8}$ platelets), indicating close agreement with the value estimated by the ${ }^{125} \mathrm{I}-\mathrm{C} \overline{1}$ INH tracer experiments. Four of these determinations did not fall within the lower limit of the linear portion of the standard curve, and, therefore, the lowest linear value of the standard curve in the individual assays was used to estimate the amount of supernatant $\mathrm{Ci}$ INH antigen. The calculated supernatant value therefore must be an overestimation. The detergent extract of washed platelets from 15 normal platelet donors was studied for total Cī INH antigen (Fig. 4). The amount of platelet $\mathrm{C}^{\overline{1}} \mathrm{INH}$ antigen detected in all extracts had a mean of $62 \pm 33 \mathrm{ng} / 10^{8}$ platelets (mean \pm SD) with a range of $33-115 \mathrm{ng} / 10^{8}$ platelets. Supernatant $C^{\overline{1}}$ INH antigen comprised $13 \%$ of the total platelet $\mathrm{C}^{\overline{1}}$ INH antigen measured in the eight donors in whom both values were determined, and in no case was it greater than the total value. In four donors with classical hereditary angioedema, the mean platelet $\mathrm{C}^{\overline{1}} \mathrm{INH}$ was $8.3 \mathrm{ng} / 10^{8}$ platelets with a range of from 5.3 to $11.3 \mathrm{ng} / 10^{8}$ platelets (Fig. 4). The ability of plasma $C \overline{1}$

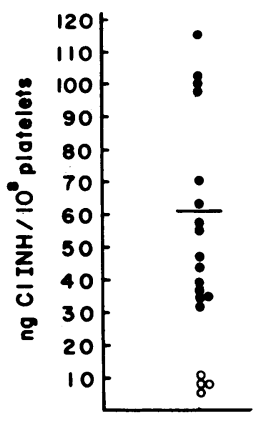

Figure 4. Total platelet $\mathrm{C} \overline{1} \mathrm{INH}$ antigen in platelet lysates. •, total platelet Cī INH antigen in platelets from normal donors. $\bigcirc$, total platelet $\mathrm{C} \overline{\mathrm{I}} \mathrm{INH}$ antigen in platelets from patients with classical hereditary angioedema. All values were determined by CELISA.

INH levels to influence platelet $C^{\overline{1}}$ INH values was studied directly by the mixing of washed platelets from a patient with hereditary angioedema with fresh normal plasma. Washed hereditary angioedema platelets with an initial platelet $\mathrm{Ci}_{\mathbf{1}}$ INH antigen concentration of $5.3 \mathrm{ng} / 10^{8}$ platelets were incubated with fresh normal plasma (Cí INH antigen, $298 \mu \mathrm{g} / \mathrm{ml}$ ) for 1 $\mathrm{h}$ at $37^{\circ} \mathrm{C}$. After the platelets were rewashed, a repeat platelet $\mathrm{C} \overline{1}$ INH level was found to be $4.8 \mathrm{ng} / 10^{8}$ platelets. This study indicated that there is little exchange between plasma and platelet pools of $\mathrm{C}^{-} \mathrm{INH}$ in unstimulated platelets and that the washing procedure adequately separated the platelets from the plasma. Platelet $\mathrm{C}^{\mathrm{l}} \mathrm{INH}$ antigen from normal platelets was immunochemically indistinguishable from plasma $C \overline{1}$ INH antigen (Fig. 5). This immunochemical identity was indicated by the capacity of $\mathrm{C}^{1} \mathrm{I}$ INH from solubilized platelets to produce complete competitive inhibition, with an inhibition curve parallel in its linear portion to that produced by plasma (two-tailed $P>0.4$ by modified Youden analysis and $P>0.3$ by paired $t$ test). Moreover, when normal platelets were mixed with platelets from a patient with classical hereditary angioedema, the total amount of the antigen present was equal to the sum of platelet $\mathrm{C} \overline{1}$ INH antigen in each donor.

Functional activity of platelet $C \bar{I} I N H$. Glycoprotein extracts of washed platelets neutralized the amidolytic activity of purified kallikrein. Since the extracts were pretreated with methylamine, a chemical inhibitor of alpha-2-macroglobulin (27), the inactivation of kallikrein must have arisen from $C \overline{1}$ INH. This $\mathrm{C}^{\overline{1}}$ INH activity had to arise from platelets since only $2 \%$ of the total amount of $\mathrm{C}_{1}^{-1}$ INH in the platelet extract could be estimated to be from plasma contamination by independent radiolabeled ${ }^{125} \mathrm{I}-\mathrm{C} \overline{1}$ INH tracer experiments. The concentration of $\mathrm{Ci}^{-1} \mathrm{INH}$ in the platelet extract was $9.2 \pm 4$ $\times 10^{8} \mathrm{M}$ (mean \pm SD for 15 determinations) for $1.14 \times 10^{10}$ platelets. This value suggested that platelets contain $84 \mathrm{ng}$ functional $\mathrm{C} \overline{1} \mathrm{INH} / 10^{8}$ platelets (range 48 to $121 \mathrm{ng} / 10^{8}$. platelets).

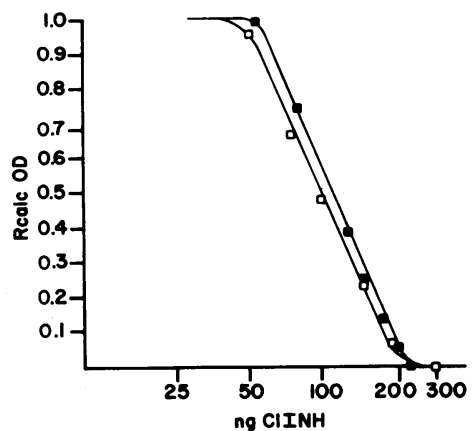

Figure 5. Competition inhibition CELISA comparing the detergent extracts of washed human platelets with plasma Cī INH. Inhibition curves produced by: $\square$, pooled normal plasma; or $n$, solubilized platelets. In the particular platelet extract analyzed, the concentration of $\mathrm{Ci}$ INH antigen was $56 \mathrm{ng} / 10^{8}$ platelets. 
Secretion of platelet $C \bar{I} I N H$. Platelet $C \overline{1}$ INH antigen was secreted from washed platelets by collagen and thrombin (Table II). At a high dose of each agonist, collagen $(20 \mu \mathrm{g} / \mathrm{ml})$ induced secretion of $25 \%$ of the total platelet Cì INH antigen, and thrombin $(1 \mathrm{U} / \mathrm{ml})$ induced secretion of $31 \%$ of the total platelet Cì INH antigen. This amount of the total antigen secreted for each agonist was less than that seen for a platelet dense granule marker-total adenine nucleotides-and a platelet alpha-granule marker-low affinity platelet Factor 4 . With collagen, $45 \%$ of the total adenine nucleotides and $52 \%$ of the total low affinity platelet Factor 4 were secreted. With thrombin, $68 \%$ of both markers was secreted. The amount of platelet Cì INH secreted from platelets during the experiments could not be accounted for by cell lysis since collagen resulted in $1.3 \%$ of platelet lactic dehydrogenase loss and thrombin accounted for none. The use of metabolic inhibitors showed that platelet Cî INH secretion was an active process. At the dose of the agonists used, metabolic inhibitors blocked $\geq 97 \%$ of the secretion of each of the platelet constituents. In two experiments, secreted platelet $\mathrm{C} \overline{1} \mathrm{INH}$ antigen did not become part of the Triton-insoluble cytoskeleton of thrombin-stimulated platelets. This finding also indicates that Triton completely solubilizes the platelet $\mathrm{C} \overline{\mathrm{i}} \mathrm{INH}$.

Platelet subcellular fractionation. Six individual platelet donors were evaluated for platelet Cī INH subcellular localization studies by differential centrifugation. In these six preparations, the mean \pm SEM recovery for total protein was $78 \pm 6 \%$; for $C^{1} \overline{~ I N H}$ antigen, $81 \pm 5 \%$; for fibrinogen antigen, $81 \pm 5 \%$; and for $\beta$ - $N$-acetyl-glucosaminidase activity, $92 \pm 4.2 \%$. When

Table II. Platelet Cī INH Secretion:

Percentage of Total in Platelets*

\begin{tabular}{llllll}
\hline & \multicolumn{2}{l}{ Washed platelets } & & \multicolumn{2}{l}{$\begin{array}{l}\text { Metabolic inhibitor-treated } \\
\text { plateletsi }\end{array}$} \\
\cline { 2 - 3 } Markers $\ddagger$ & Collagen" & Thrombin** & & Collagen" & Thrombin** \\
\hline Cī INH & $25 \pm 6$ & $31 \pm 1.3$ & & $0.3 \pm 0.3$ & 0 \\
ADP/ATP & $45 \pm 16$ & $68 \pm 11$ & & $1.3 \pm 1.3$ & 0 \\
LA-PF & $52 \pm 11$ & $68 \pm 6.2$ & & 0 & $0.4 \pm 0.4$ \\
LDH & $1.3 \pm 1.3$ & 0 & & 0 & 0
\end{tabular}

* The platelet agonist was introduced into the platelet suspension and it was stirred at $1,200 \mathrm{rpm}$ at $37^{\circ} \mathrm{C}$. The total time from the introduction of the stimulus till the end of stirring was $10 \mathrm{~min}$. Values represent the percentage total secretion, which was determined from the ratio of agonist-treated specimen to the total amount present in detergent lysate after concomitant nonstimulated platelet supernatants were subtracted from both. Values expressed are the means \pm SEM of three experiments, each consisting of combined platelets from two donors.

‡ ADP/ATP, total adenine nucleotides; $L A-\mathrm{PF}_{4}$, low affinity-platelet Factor 4; LDH, lactic dehydrogenase. Cī INH was assayed by CELISA. See Methods for each other assay procedure.

$\S$ Washed platelets were prepared by albumin density gradient centrifugation and gel filtration (see Methods).

I Metabolic inhibitor-treated platelets were platelets incubated with a mixture of antimycin $A(15 \mu \mathrm{g} / \mathrm{ml}), 2$-deoxy-D-glucose $(30 \mathrm{mM})$, and D-gluconic acid $\delta$-lactone $(10 \mathrm{mM})$ for $30 \mathrm{~min}$ at $37^{\circ} \mathrm{C}$.

"Collagen was introduced in the cuvette in a final concentration of $20 \mu \mathrm{g} / \mathrm{ml}$.

** Thrombin was introduced in the cuvette in a final concentration of $1 \mathrm{U} / \mathrm{ml}$.

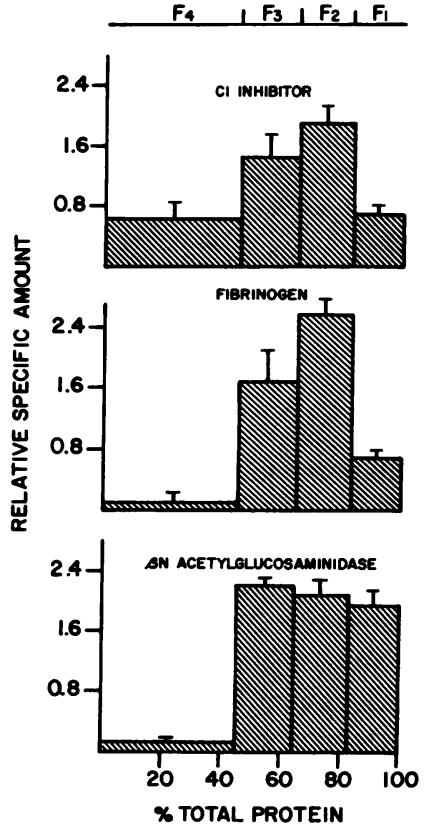

washed lysed platelets were subjected to differential centrifugation, the largest amount, as indicated by the area under the graph, of platelet $\mathrm{Ci}$ INH antigen and of fibrinogen antigen emerged in the $12,000 \mathrm{~g}$ pellet (fraction $\mathrm{F}_{2}$ ), a fraction enriched with platelet granules and mitochondria (Fig. 6).

In an attempt to separate further the components of the granule fraction, the $F_{2}$ was subjected to sucrose density ultracentrifugation (Fig. 7). In six experiments, the mean \pm SEM recovery for total protein was $88 \pm 8 \%$; $C \overline{1}$ INH antigen, $96 \pm 14 \%$; fibrinogen antigen, $90 \pm 9 \% ; \beta-N$-acetyl-glucosaminidase, $77 \pm 5 \%$; and serotonin, $98 \pm 4.4 \%$. Upon sucrose density ultracentrifugation, $80 \%$ of the Cì INH antigen from the $\mathrm{F}_{2}$ fraction entered the gradient (i.e., moved into fractions $B$ through $F$ ), indicating that platelet $C \overline{1}$ INH was contained mostly within platelet granules. Moreover, $81 \%$ of granule $C \overline{1}$ INH antigen $\left(65 \%\right.$ of the total Cì INH antigen from the $F_{2}$

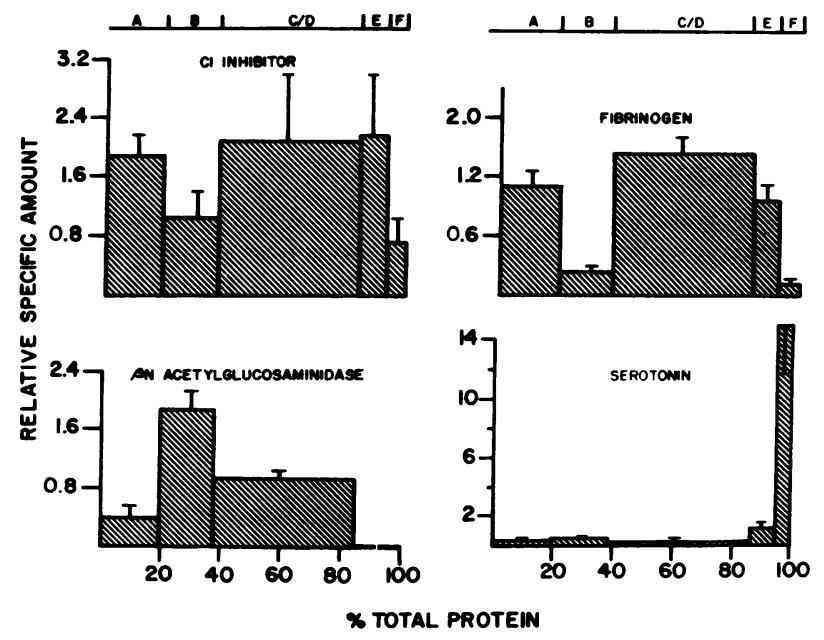

Figure 7. Platelet subcellular fractionation by sucrose density ultracentrifugation of fraction $F_{2}$ from Fig. 6. All data are plotted as in Fig. 6. 
fraction), as indicated by the area under the graph, was localized to the C/D and E fractions (Fig. 7), fractions previously characterized to be enriched with platelet alpha-granules (4850). This localization was similar to that of platelet fibrinogen, a recognized platelet alpha-granule constituent (2), but distant from $\beta-N$-acetyl glucosaminidase, a lysosomal granule constituent; and serotonin, a dense granule constituent. These combined studies suggest that platelet $\mathrm{C} \overline{1}$ INH is mostly a platelet alpha-granule protein.

\section{Discussion}

The results from these experiments show that human platelets contained, by immunological criteria, $\mathrm{Ci}^{-} \mathrm{INH}$ at an average concentration in normal platelets of $62 \mathrm{ng} / 10^{8}$ platelets (Fig. 4). In contrast, platelets from patients with classical hereditary angioedema had an average concentration of platelet $\mathrm{Ci}^{-}$INH of $8.3 \mathrm{ng} / 10^{8}$ platelets. Two independent approaches, ${ }^{125} \mathrm{I}-\mathrm{C} \overline{1}$ INH tracer studies and direct measurement of $\mathrm{C}^{-1} \mathrm{INH}$ antigen in platelet supernatants from each individual normal donor, estimate that contaminating plasma $\mathrm{C}_{1} \overline{\mathrm{I}}$ INH could account for only from 7.9 to $10.5 \mathrm{ng} / 10^{8}$ platelets of the total amount of $\mathrm{Ci}^{-1} \mathrm{INH}$ antigen measured in the aliquots of each normal platelet lysate as determined by the CELISA. Therefore, plasma contamination could contribute at most only $16 \%$ of the $C \overline{1}$ INH detected in solubilized platelets. The measured value for platelet $C_{1} \bar{I}$ INH on the CELISA appears to represent intracellular platelet $\mathrm{C} \overline{1}$ INH, since $\mathrm{C} \overline{1}$ INH antigen is not detected $\left(<6.6 \mathrm{ng} / 10^{8}\right.$ platelets) on the unstimulated platelet surface in an indirect antibody consumption assay (Fig. 3). Furthermore, the two pools of $\mathrm{C}^{-} \mathrm{INH}$, plasma and platelet, were not exchangeable, since washed platelets from a patient with hereditary angioedema did not increase their $C \overline{1}$ INH levels after incubation in normal plasma. Finally, platelet $\mathrm{C}_{\overline{1}} \mathbf{I N H}$ functions like plasma $C_{\overline{1}} \overline{I N H}$ since it can neutralize the amidolytic of purified kallikrein. Upon functional assay, normal platelets are shown to contain amounts of $\mathrm{Ci}^{\mathbf{1}}$ INH activity similar to those determined by antigen studies.

The finding that platelet $\mathrm{C}^{-} \mathbf{I}$ INH is secreted upon stimulation by collagen and thrombin and that this secretion is an energy-requiring process without cell lysis provides a mechanism by which this protein can be made available since it is not found on the surface of unstimulated platelets. The finding that only 25 to $31 \%$ of the total amount of platelet $\mathrm{C}^{\overline{1}}$ INH is detected in the suspending medium after platelet stimulation with high agonist concentration needs clarification. There are three possible explanations for this finding. High molecular weight plasma proteins associated with platelet granules may be secreted differently than low molecular weight plateletspecific proteins such as low affinity platelet Factor 4 (47). A higher percentage of this protein may have been secreted but a large portion of it rapidly rebound to the platelet surface. Finally, only a small percentage of the total granule content of this protein was secreted, the rest remaining in granules that became expressed on the activated platelet surface. The two latter mechanisms could provide a means whereby platelet Cí INH is expressed in high concentrations on the platelet surface. However, platelet $\mathrm{C}_{1} \overline{1}$ INH was not detectable on Triton-insoluble, thrombin-stimulated platelet cytoskeletons prepared by one technique (48), suggesting that it does not become a cytoskeletal component after platelet activation. The secretion of only 25 to $40 \%$ of the total platelet content of a high molecular weight hemostatic cofactor contained within platelet alpha-granules, in contrast to low affinity platelet Factor 4 (47), has been noted previously for platelet fibronectin (54), high molecular weight kininogen $(12,55)$, and von Willebrand factor (11).

Platelet subcellular fractionation studies indicate that $\mathbf{8 0 \%}$ of platelet $\mathrm{C}^{\bar{l}}$ INH in the unstimulated platelet is found in those granule fractions that contain alpha-granules (Fig. 7). The relative absence of any significant amount of the protein in the F pellet on the sucrose gradient (Fig. 7), the area where platelet serotonin is largely concentrated, excludes the possibility that platelet $\mathrm{C}_{1} \overline{\mathrm{I}}$ INH is a dense granule protein. Although $20 \%$ of platelet $\mathrm{Ci}^{-1} \mathrm{INH}$ from the $\mathrm{F}_{2}$ fraction was found in the $A$ fraction (soluble portion) of the sucrose gradient (Fig. 7), the presence of an equally large amount of platelet fibrinogen in this fraction suggests that some granules may have been lysed in resuspension of the $F_{2}$ pellet (Fig. 6) and transfer of it to the gradient for ultracentrifugation. Further confirmation of a platelet alpha-granule localization for platelet $\mathrm{C} \overline{1}$ INH in the unstimulated platelet requires studies on the total content of platelet $\mathrm{C} \overline{\mathbf{1}}$ INH in gray platelets (56).

The platelet $\bar{C} \overline{1}$ INH level for $3 \times 10^{8}$ platelets $/ \mathrm{ml}$ plasma is $183 \mathrm{ng}$, which constitutes $0.08 \%$ of the plasma level of 230 $\mu \mathrm{g} / \mathrm{ml}$. This value is similar to that which has been determined for platelet alpha-2-macroglobulin (0.04\%) (13), alpha-1-antitrypsin $(0.007 \%)(13,14)$, and alpha-2-antiplasmin $(0.03 \%)$ (20). However, since platelets are concentrated within the fibrin clot, local concentrations of secreted platelet $\mathrm{Ci}^{-}$INH may exceed physiologic plasma amounts. If platelets secrete their granules by exocytosis and platelet granules are about one-tenth of the volume of platelets (the volume of $10^{11}$ platelets is $0.7 \mathrm{ml}$ [57]), the concentration of platelet $\mathrm{C} \overline{\mathbf{1}}$ INH in granules at the platelet surface during secretion could be $\sim 2.6 \mathrm{mg} / \mathrm{ml}$ for 300,000 platelets $/ \mu \mathrm{l}, 10$ times its concentration in plasma. In contrast, activated platelets from the patients with hereditary angioedema could only achieve levels of $C \overline{1}$ INH similar to the concentration of $\mathrm{C}^{-} \mathrm{INH}$ in normal plasma. This interpretation enhances the physiologic potential of platelet Cì INH, since localized concentrations of the magnitude achievable by normal platelets may effectively promote inhibition of contact-phase proteases (22-25). Recent studies on platelet high molecular weight kininogen indicate that at least a portion equal to that secreted into the suspending medium also becomes expressed on the activated platelet surface (55). This finding suggests that high local concentrations of platelet forms of plasma proteins may be achieved on the activated platelet surface. The finding that platelets contain both the major cofactor (high molecular weight kininogen) (12) and inhibitor (Cī INH) to contact phase activation, without containing the protease (kallikrein) (unpublished data) suggests that the platelet locus may be an important site of modulation of surface-activated defense mechanisms involved in complement activation $(58,59)$ and early blood coagulation.

Note added in proof. We recently studied platelets from a patient with the gray platelet syndrome (patient $R$. K. (5b), courtesy of Dr. J. G. White, University of Minnesota). The total platelet CīINH content in these platelets was $26 \mathrm{ng} / 10^{8}$ platelets (42\% of normal).

\section{Acknowledgments}

We would like to express our appreciation to Ms. Gail Pakstis, Ms. Sandra Wadsworth, and Ms. Carol Silverman for technical assistance; 
Ms. Pat Pileggi for the preparation of the manuscript; Drs. Boguslaw Rucinski and Stefan Niewiarowski for their help in performing the low-affinity platelet Factor 4 assays; Dr. Leon Salganicoff for his advice on platelet subcellular fractionation; and Drs. Howard Barsky and Charles Blumstein for allowing us to study their hereditary angioedema patients.

This work was supported in part by a National Heart, Lung, and Blood Institute Clinical Investigator's Award (HL-00694), a Temple University Biomedical Research Support Grant (S07 RR05417), and an American Heart Association Grant-In-Aid (81725) to Dr. Schmaier; and by a National Institutes of Health Research Grant (HL 24365), a Specialized Centers of Research grant (HL 14217), and a grant from the Council for Tobacco Research (1420) to Dr. Colman.

\section{References}

1. Nachman, R. L., A. J. Marcus, and D. Zucker-Franklin. 1967. Immunologic studies of proteins associated with subcellular fractions of normal human platelets. J. Lab. Clin. Med. 69:651-658.

2. Broekman, M. J., R. I. Handin, and P. Cohen. 1975. Distribution of fibrinogen and platelet factor 4 and XIII in subcellular fractions of human platelets. Br. J. Haematol. 31:51-55.

3. Keenan, J. P., and N. O. Solum. 1972. Quantitative studies on the release of platelet fibrinogen by thrombin. Br. J. Haematol. 23:461466.

4. Breederveld, K., J. C. Giddings, J. W. Ten Cate, and A. L. Bloom. 1975. The localization of factor $V$ within normal human platelets and the demonstration of a platelet factor $\mathrm{V}$ antigen in congenital factor V deficiency. Br. J. Haematol. 29:405-412.

5. Osterud, B., S. I. Rapaport, and K. K. Lavine. 1977. Factor V activity of platelets: evidence for an acitvated factor $\mathrm{V}$ molecule and for a platelet activator. Blood. 49:819-834.

6. Kane, W. H., M. J. Lindout, C. M. Jackson, and P. W. Majerus. 1980. Factor Va-dependent binding of factor $\mathrm{Xa}$ to human platelets. J. Biol. Chem. 255:1170-1174.

7. Vicic, W. J., B. Lages, and H. J. Weiss. 1980. Release of human platelet factor $\mathrm{V}$ activity is induced by both collagen and ADP and is inhibited by aspirin. Blood. 56:448-455.

8. Chesney, C. M., D. Pifer, and R. W. Colman. 1981. Subcellular localization and secretion of factor $\mathrm{V}$ from human platelets. Proc. Natl. Acad. Sci. USA. 78:5180-5184.

9. Nachman, R. L., and E. A. Jaffe. 1975. Subcellular platelet Factor VIII antigen and von Willebrand factor. J. Exp. Med. 141:11011113.

10. Zucker, M. B., M. J. Broekman, and K. L. Kaplan. 1979. Factor VIII-related antigen in human blood platelets. J. Lab. Clin. Med. 94:675-682.

11. Koutts, J., P. N. Walsh, E. F. Plow, J. W. Fenton, B. N. Bouma, and T. S. Zimmerman. 1978. Active release of human platelet Factor VIII-related antigen by adenosine diphosphate, collagen, and thrombin. J. Clin. Invest. 621:1255-1263.

12. Schmaier, A. H., A. Zuckerberg, C. Silverman, J. Kuchibhotla, G. P. Tuszynski, and R. W. Colman. 1983. High molecular weight kininogen. A secreted platelet protein. J. Clin. Invest. 71:1477-1489.

13. Nachman, R. L., and P. C. Harpel. 1976. Platelet $\alpha_{2}$ macroglobulin and $\alpha_{1}$ antitrypsin. J. Biol. Chem. 251:4514-4521.

14. Bagdasarian, A., and R. W. Colman. 1978. Subcellular localization and purification of platelet $\alpha_{1}$ antitrypsin. Blood. 51:139-156.

15. Wakabayashi, K., K. Fujikawa, and T. Abe. 1970. Some properties of an antiplasmin substance from rabbit platelets. Thromb. Diath. Haemorrh. 24:76-84.

16. Ganguly, P. 1972. A low molecular weight antiplasmin of human blood platelets. Clin. Chim. Acta. 39:466-468.

17. Mui, P. T. K., H. L. James, and P. Ganguly. 1975. Isolation and properties of a low molecular weight antiplasmin of human blood platelets and serum. Br. J. Haematol. 29:627-637.

18. Moore, S., D. Pepper, and J. D. Cash. 1975. The isolation and characterization of a platelet-specific beta-globulin ( $\beta$ thromboglobulin) and the detection of anti-urokinase and antiplasmin released from thrombin-aggregated washed human platelets. Biochim. Biophys. Acta. 379:360-369.

19. Joist, J. H., S. Niewiarowski, N. Nath, and J. F. Mustard. 1976. Platelet antiplasmin: its extrusion during the release reaction, subcellular localization, characterization and relationship to antiheparin in pig platelets. J. Lab. Clin. Med. 87:659-669.

20. Plow, E. F., and D. Collen. 1981. The presence and release of $\alpha_{2}$ antiplasmin from human platelets. Blood. 58:1069-1074.

21. Endresen, G. K. M. 1980. Immunological studies of plasma protease inhibitors associated with human blood platelets. Thromb. Res. 19:157-163.

22. Schapira, M., C. F. Scott, and R. W. Colman. 1982. Contribution of plasma protease inhibitors to the inactivation of kallikrein in plasma. J. Clin. Invest. 69:462-468.

23. Van der Graff, F., J. A. Koedam, and B. N. Bouma. 1983. Inactivation of kallikrein in human plasma. J. Clin. Invest. 71:149159.

24. Forbes, C. D., J. Pensky, and O. D. Ratnoff. 1970. Inhibition of activated Hageman factor and activated thromboplastin antecedent by purified Cī inactivator. J. Lab. Clin. Med. 76:809-815.

25. Schreiber, A. D., A. P. Kaplan, and K. F. Austen. 1973. Plasma inhibitors of the components of the fibrinolytic pathway in man. $J$. Clin. Invest. 52:1402-1409.

26. Laurell, A. B., U. Johnson, U. Martensson, and A. G. Sjoholm. 1978. Formation of complexes composed of $C \overline{1} r, C \bar{s} s$, and $C \bar{l}$ inactivator in human serum on activation of Cī. Acta Pathol. Microbiol. Scand. Sect. C Immunol. 86:299-306.

27. Schapira, M., L. D. Silver, C. F. Scott, and R. W. Colman. 1982. New and rapid functional assay for $C^{1} \bar{l}$ inhibitor in human plasma. Blood. 59:719-724.

28. Schmaier, A. H., W. Claypool, and R. W. Colman. 1980. Crotalocytin: recognition and purification of a timber rattlesnake platelet aggregating protein. Blood. 56:1013-1019.

29. Sim, R. B., and A. Reboul. 1981. Preparation and properties of human $\mathrm{Cl}$ inhibitor. Methods Enzymol. 80:43-54.

30. Howe, C., L. T. Lee, A. Harboe, and G. Haukenes. 1967. Immunochemical study of influenza virus and associated host tissue components. J. Immunol. 98:543-557.

31. Laemmli, U. K. 1970. Cleavage of structural proteins during the assembly of the head of bacteriophage T4. Nature (Lond.). 227:680685.

32. Ouchterlony, O., and L. A. Nilsson. 1978. Immunodiffusion and immunoelectrophoresis. In Handbook of Experimental Immunology. Third ed. D. M. Weir, editor. Blackwell Scientific Publications Ltd, Oxford. 19.1-19.44.

33. Bradford, M. M. 1976. Rapid and sensitive method for the quantitation of microgram quantities of protein utilizing the principle of protein-dye binding. Anal. Biochem. 72:248-254.

34. Scopes, R. K. 1974. Measurement of protein by spectrophotometry at $205 \mathrm{~nm}$. Anal. Biochem. 59:277-282.

35. Fraker, P. J., and S. C. J. Speck. 1978. Protein and cell membrane iodinations with a sparingly soluble chloramide 1,3,4,6tetrachloro-3 $\alpha-6 \alpha$-diphenylglycoluril. Biochem. Biophys. Res. Commun. 80:849-857.

36. Mancini, G. A., A. O. Carbonara, and J. E. Heremans. 1964. Immunochemical quantification at antigens by single radial immunodiffusion. Immunochemistry. 2:235-254.

37. Laurell, C. B. 1966. Quantitative estimation of proteins by electrophoresis in agarose gel containing antibodies. Anal. Biochem. 15:45-52.

38. Canellas, P. F., and A. E. Karu. 1981. Statistical package for analysis of competitive ELISA results. J. Immunol. Methods. 47:375385.

39. Youden, W. J. 1960. The sample, the procedure, and the laboratory. Anal. Chem. 32:23A-37A.

40. Tuszynski, G. P., S. J. Bevacqua, A. H. Schmaier, R. W. 
Colman, and P. N. Walsh. 1982. Factor XI antigen and activity in human platelets. Blood. 59:1148-1156.

41. Gigli, I., J. W. Mason, R. W. Colman, and K. F. Austen. 1970. Interaction of plasma kallikrein with the $\mathrm{C} \overline{1}$ inhibitor. J. Immunol. 104:574-581.

42. Schapira, M. A., C. F. Scott, and R. W. Colman. 1981. Protection of human plasma kallikrein from inactivation by $\mathrm{C} \overline{\mathbf{I}}$ inhibitor and other protease inhibitors. Biochemistry. 20:2738-2743.

43. Schmaier, A. H., and R. W. Colman. 1980. Crotalocytin: characterization of the timber rattlesnake platelet activating protein. Blood. 56:1020-1028.

44. Holmsen, H., and J. N. Akkerman. 1980. The requirement for ATP availability in platelet response-a quantitative approach. In The Regulation of Coagulation. K. G. Mann and F. B. Taylor, Jr., editors. Elsevier/North Holland Biomedical Press, New York. 409-417.

45. Holmsen, H., E. Storm, and H. J. Day. 1972. Microdetermination of ADP and ATP in blood platelets: a modification of the plasma method. Anal. Biochem. 46:489-501.

46. Wroblewski, F., and J. S. Ladue. 1955. Lactic dehydrogenase activity in blood. Proc. Soc. Exp. Biol. Med. 90:210-213.

47. Rucinski, B., S. Niewiarowski, P. James, D. A. Walz, and A. Budzynski. 1979. Antiheparin proteins secreted by human platelets, purification, characterization, and radioimmunoassay. Blood. 53:4762.

48. Tuszynski, G. P., P. N. Walsh, J. R. Piperno, and A. Koshy. 1982. Association of coagulation factor $\mathrm{V}$ with the platelet cytoskeleton. J. Biol. Chem. 257:4557-4563.

49. Fukami, M. H., J. S. Bauer, G. J. Stewart, and L. Salganicoff. 1978. An improved method for the isolation of dense storage granules from human platelets. J. Cell Biol. 77:389-399.

50. Salganicoff, L., and M. H. Fukami. 1972. Energy metabolism of blood platelets. I. Isolation and properties of platelet mitochondria. Arch. Biochem. Biophys. 153:726-735.

51. Salganicoff, L., P. A. Hebda, J. Yandrasitz, and M. H. Fukami. 1975. Subcellular fractionation of pig platelets. Biochim. Biophys. Acta. 385:394-411.

52. Day, H. J., H. Holmsen, and T. Hovig. 1969. Subcellular particles of human platelets. Scand. J. Haematol. 7(Suppl.):3-35.

53. Weissbach, H., T. P. Waalkes, and S. Udenfriend. 1958. A simplified method for measuring serotonin in tissues: simultaneous assay of both serotonin and histamines. J. Biol. Chem. 230:865-871.

54. Ginsberg, M. H., R. G. Painter, C. Birdwell, and E. F. Plow. 1979. The detection, immunofluorescent localization and thrombininduced release of human platelet-associated fibronectin antigen. $J$. Supramol. Struct. 11:167-174.

55. Schmaier, A. H., P. M. Smith, and R. W. Colman. 1984. High molecular weight kininogen: localization in unstimulated and activated platelets and activation by a platelet cysteine protease. Circulation. 70: II-352 (Abstr.).

56. Gerrard, J. M., D. R. Phillips, G. H. R. Rao, E. F. Plow, D. A. Walz, R. Ross, L. A. Harker, and J. G. White. 1980. Biochemical studies of two patients with the gray platelet syndrome. J. Clin. Invest. 66:102-109.

57. Holmsen, H., and L. Robkin. 1980. Effects of antimycin A and 2-deoxyglucose on energy metabolism in washed human platelets. Thromb. Haemostasis. 42:1460-1472.

58. Ghebrehiwet, B., M. Silverberg, and A. P. Kaplan. 1981. Activation of the classical pathway of complement by Hageman factor fragment. J. Exp. Med. 153:665-676.

59. Ghebrehiwet, B., B. P. Randazzo, J. T. Punn, M. Silverberg, and A. P. Kaplan. 1983. Mechanism of activation of the classical pathway of complement by Hageman factor fragment. J. Clin. Invest. $71: 1450-1456$. 